\title{
Synthesis and antibacterial activity of epoxide from hyptolide (Hyptis pectinata (L.) Poit) against Gram-positive and Gram- negative bacteria
}

\author{
Bambang Cahyono $^{1 *}$, Meiny Suzery ${ }^{1}$, Nur Dina Amalina ${ }^{2}$, Wahyudi ${ }^{1}$, Damar Nurwahyu Bima ${ }^{1}$ \\ ${ }^{1}$ Chemistry Department, Faculty of Sciences and Mathematics, Diponegoro University, Semarang, Indonesia. \\ ${ }^{2}$ Pharmacy Study Program, Chemistry Department, Faculty of Mathematics and Natural Sciences, Universitas Negeri Semarang, Semarang, Indonesia.
}

\begin{tabular}{l}
\hline ARTICLE INFO \\
\hline Received on: $25 / 03 / 2020$ \\
Accepted on: 01/10/2020 \\
Available online: 05/12/2020 \\
\hline Key words: \\
Hyptis pectinata (L.) Poit, \\
mCPBA epoxidation, \\
hyptolide, Gram-positive and \\
Gram-negative bacteria.
\end{tabular}

\section{INTRODUCTION}

Hyptis pectinata (L.) Poit is a family Lamiaceae plant that can be found in tropical areas such as Brazil, Mexico, India, and Indonesia. This plant popularly known in northeast Brazil as "sambacaita" or "canudinho" is an aromatic herbaceous plant clustered in axillary inflorescences with small bilabial flowers (Basílio et al., 2006; Franzotti et al., 2001). In Indonesia, Hyptis

\footnotetext{
"Corresponding Author

Bambang Cahyono, Chemistry Department, Faculty of Sciences and Mathematics, Diponegoro University, Semarang, Indonesia.

E-mail: cahyono@live.undip.ac.id
}

\begin{abstract}
Recently, drug resistance due to excessive use of antibiotics has become a severe problem, and alternative antibiotics' evelopment has become an urgent problem. Epoxy hyptolide is a compound of the synthesis of hyptolide through the study aimed to investigate the relationship between hyptolide and its epoxide structure on the antibacterial activity against Gram-positive and Gram-negative bacteria. The results indicated that epoxy hyptolide was a successful synthesis of hyptolide from the isolation of the leaves of Hyptis pectinata (L.) Poit using the mCPBA. The chemical characterization of hyptolide and its epoxidation revealed a melting point of $86.9^{\circ} \mathrm{C}-87.8^{\circ} \mathrm{C}$ and $79^{\circ} \mathrm{C}-80^{\circ} \mathrm{C}$, on wavenumbers $1,250 \mathrm{~cm}^{-1}$ and $814 \mathrm{~cm}^{-1}$. On the other hand, a detailed ${ }^{1} \mathrm{H}$ nuclear magnetic resonance spectrum of a chemical shift of $3.5 \mathrm{ppm}$ indicated the presence of an oxygen ring due to the transformation of $\mathrm{C}=\mathrm{C}$ olefin double bond into an epoxide form. Furthermore, the test of the antibacterial activity of hyptolide and epoxy hyptolide was carried out by disk diffusion method. The results revealed that hyptolide and epoxy hyptolide have a border Bacillus subtilis and the IZ was found to be $28.00 \mathrm{~mm}$ in comparison with amoxicillin as the control had $7.58 \mathrm{~mm} \mathrm{IZ.}$ Interestingly, the most effective antibacterial activity in Salmonella typhi caused by the presence of epoxy hyptolide with the maximum IZ was $21.80 \mathrm{~mm}$, compared to amoxicillin that had $6.320 \mathrm{~mm}$ IZ. It can be concluded that Gramnegative bacteria was more susceptible to epoxy hyptolide in comparison to hyptolide. The cell wall structure of the Gram-positive and Gram-negative bacteria could be the main reason for the bacteria's susceptibility.
\end{abstract}

pectinata has not been cultivated, but it grows wild and is underutilized by the community (Suzery et al., 2012). The plant has a lot of chemical compounds and biological activities as reported earlier (Luzuriaga-Quichimbo et al., 2018; Suzery et al., 2020). The phytochemical content of Hyptis pectinata generally has a skeleton of $\alpha, \beta$-unsaturated lactones, such as hyptolide compounds (Achmad et al., 1987), pectinolides A-C, sambacaitaric acid, rosmarinic acid (Falcao et al., 2013), pectinolides D-G (Boalino et al., 2003), and spicigerolide (Almtorp et al., 1991). The discovery of $\alpha, \beta$-unsaturated lactones is an interesting study because of its potential effect as antinociceptive, antiedematogenic (Franzotti et al., 2001), antileishmanial (Falcao et al., 2013), antimalarial (Melo et al., 2006), antibacterial (Santos et al., 2008), and anticancer (Asy 
and Suzery, 2019; Amalina et al., 2020; Suzery et al., 2020). The previous study reported that hyptolide has a basic framework of $\alpha$, $\beta$-unsaturated $\mathrm{C} 12-\delta$-lactones with a chemical formula, $\mathrm{C}_{18} \mathrm{H}_{24} \mathrm{O}_{8}$ (Achmad et al., 1987). The structure has a center of action in the isolated olefin group. The transformation of an isolated olefin group contained in hyptolide (C6-C7) was successfully carried out by our research group through the reaction using metachloroperoxybenzoic acid (mCPBA) oxidizer. Unfortunately, the activity of the transformation structure of hyptolide has never been explored, whereas previous research explained that the functional group has a crucial role in the activity. Among these properties are antimicrobial activities exhibited by the epoxide structure of the compound (Husain and Shaharyar, 2015). Erythromycin is modified to be 10,11-epoxy acylide erythromycin which is shown to increase its antibacterial activity (Nie et al., 2013). The study supported the previous research results that epoxides derived from chalcones increase antibacterial activity against Gram-positive and Gram-negative bacteria (Husain and Shaharyar, 2015). Other studies also explained that the oxirane ring in the epoxide structure has an important role as antibacterial (Thirunarayanan and Vanangamudi, 2016). Based on these data, in this study, we evaluated the relationship between the structure of hyptolide and its transformation of epoxy hyptolide in the antimicrobial activity against Gram-positive and Gram-negative bacteria.

\section{MATERIAL AND METHODS}

\section{Plant material}

The herbs of Hyptis pectinata were collected from the local area East Kanayakan Dago, Bandung, Indonesia (latitude -7.0460282; longitude 107.7915393). The plant material was classified and authenticated by a biologist at the Ecology and Biosystematics Laboratory, Faculty Science and Mathematics, Diponegoro University, Indonesia. A reference specimen of the plant is deposited with a voucher number of MS 100562 at the Herbarium Biology, Faculty Science and Mathematics, Diponegoro University, Indonesia.

\section{Isolation and purification of hyptolide}

The extraction process of the dried Hyptis pectinata (L.) Poit was carried out using percolation and isolation of the hyptolide crystal by fractionations, followed by the literature procedure (Achmad et al., 1987; Meiny et al., 2012). After isolation, the purification of hyptolide crystals was carried out by the recrystallization method according to a previous research study with slight modification (Suzery et al., 2019). Recrystallization methods use ether to dissolve the hyptolide. Then, the filtrate was filtered using a Buchner funnel to obtain pure hyptolide crystals. The hyptolide crystals analyzed its purity through melting point test and chromatography using silica gel G60 F254 thin-layer chromatography (TLC) in $60 \%$ ether $/ 40 \%$ chloroform and tested antibacterial activity against five types of bacteria.

\section{Synthesis and characterization of epoxy hyptolide}

Epoxidation procedures were prepared according to our previous research protocols (Suzery, 1989) with some modifications according to Bradley et al. (1997) and Hussain et al. (2014). It was prepared by mixing the hyptolide $(368 \mathrm{mg})$, which is weighed into a $100 \mathrm{ml}$ round bottom flask, with $\mathrm{CHCl}_{3}(15 \mathrm{ml})$, benzoic acid $\left(\mathrm{C}_{6} \mathrm{H}_{5} \mathrm{COOH} 345 \mathrm{mg}\right), \mathrm{mCPBA}(20 \mathrm{mg})$, and a magnetic stirrer which are introduced into the flask and the mixture is stirred and cooled at $0^{\circ} \mathrm{C}$ for 24 hours. Furthermore, determining the end of the epoxidation reaction was confirmed by the similarity of retention time value using TLC. The resultant product was purified using the recrystallization method as described previously.Identification of the crystals was obtained using nuclear magnetic resonance (NMR) and Fourier-transform infrared (FTIR) according to Ahmad et al. (2014) and Suzery et al. (2019). NMR spectrometry was carried out by using Nanalysis-type ready NMR, Canada. ${ }^{1} \mathrm{H}$ spectra were measured at $500 \mathrm{MHz}$. Approximately, $2 \mathrm{ml}$ of each sample was dissolved in $2 \mathrm{ml}$ of nondeuterated chloroform $\left(\mathrm{CDCl}_{3}\right)$ (Sigma-Aldrich-288306), placed in the NMR tube to produce a sample depth of approximately 3.5 to $4 \mathrm{~cm}^{-1}$ and ready for NMR spectrometer analysis. The description of the type of ${ }^{1}$ HNMR detected was based on the characteristic NMR absorption table published in Organic Chemistry (Janice, 2008).

Furthermore, to prove the presence of an oxirane ring function group as a marker of epoxide formation by using FTIR (Perkin Elmer), the crystalline samples were introduced directly into FTIR. The scan range employed was from 400 to $4,000 \mathrm{~cm}^{-1}$ with a resolution of $4 \mathrm{~cm}^{-1}$. The chemical bond in a molecule was detected by interpreting the infrared transmittance spectrum. The identification of the functional group in the compound was based on the table of characteristic IR absorptions published in Organic Chemistry (Janice, 2008).

\section{Bacterial and growth conditions}

The bacterial spp. used for the test were Gram-positive: Bacillus subtilis ATCC 6633, Staphylococcus aureus FNCC-0047, and Streptococcus mutants ATCC 26176, and gram-negative: Escherichia coli ATCC 35218 and Salmonella typhi ATCC 19430. All the stock cultures were collected from the integrated laboratory unit, Diponegoro University, Semarang, Indonesia. All the bacterial strains used in this study were maintained by subculturing them for $24-48$ hours at $37^{\circ} \mathrm{C}$ on the nutrient agar/broth (Merck)

\section{Antibacterial activity assay}

The extract, hyptolide, and epoxy hyptolide were screened for their antibacterial activity in comparison with the standard antibiotic amoxicillin $(25 \mathrm{mg} / \mathrm{ml})$ by disk diffusion method according to Mama et al. (2019) and Razmavar et al. (2014) using Bacillus subtilis, Staphylococcus aureus, Streptococcus mutants, Escherichia coli, and Salmonella thyposa as test organisms. This method possesses the potential to see growth inside of the plate and the colony can be visualized in the inhibitory zone (Sachdeva et al., 2015).

Bacterial suspension of $0.5 \mathrm{McF}$ arland $\left(1.5 \times 10^{8}\right.$ colony forming unit $\mathrm{CFU} / \mathrm{ml}$ ) was obtained from all the bacterial strains and then, surface culture was carried out by spreading with a sterile cotton swab on Mueller Hinton agar (Merck). Each sample was individually loaded on the $6 \mathrm{~mm}$ sterile disk at concentrations of 25,50 , and $75 \mathrm{mg} / \mathrm{ml}$ and subjected to antibacterial activity. For negative control, the disks were loaded with $10 \%$ dimethyl sulfoxide (Sigma-Aldrich). After diffusion of the sample into the medium, the plates were incubated for 24 hours at a temperature 
of $37^{\circ} \mathrm{C}$. After incubation, antibacterial activity was evaluated by measuring the diameter of the inhibition zone (IZ) around the disks using a caliper. The assay was repeated thrice. Antibacterial activity was expressed as the mean zone of inhibition diameters ( $\mathrm{mm}$ ) produced by each sample. The diameter of the IZ was considered resistant or not sensitive $(8.0 \mathrm{~mm})$, moderately sensitive $(8.0-14.0$ $\mathrm{mm}$ ), relatively sensitive (14-20 $\mathrm{mm}$ ), and extremely sensitive by more than $20 \mathrm{~mm}$ (Singh Arora et al., 2009).

\section{Statistical analysis}

The results were expressed as mean \pm SEM. Statistical analysis of the data was carried out using one-way ANOVA and the results were considered significant when $p<0.05$.

\section{RESULTS AND DISCUSSION}

Antibiotic resistance is harmful to human health because most infectious organisms recognize and establish a tolerance for the mechanism of drug action (Peterson and Kaur, 2018; Zhang et al., 2018). Because of frequent resistance development and the potentially harmful effect on the use of conventional antibacterial drugs (Founou et al., 2017; Matsunaga and Hayakawa, 2018), there is continuous research to explore new natural antibacterial agents to reduce resistance side effects and improve efficacy against infectious microorganisms (Andrade et al., 2017). Hyptis pectinata extract is one of the natural agents which can potentially be developed as an anticancer, antioxidant, and antibacterial (Amalina et al., 2020; Santana et al., 2019; Suzery et al., 2020). Nevertheless, tests of the antibacterial activity of hyptolide have never been attempted. In comparison, the epoxy ring was found to be the polar form of the nature of carbonyl group responsible for the medical activities. Some natural epoxide demonstrated biological activities (Marco-Contelles et al., 2004). Generally, epoxide possesses many biological activities, such as antianalgesic activity (Inceoglu et al., 2008), anti-inflammation (Morisseau et al., 2012), cytotoxicity (Ye et al., 2002), and tumorigenicity (Pal et al., 2013). Hence, the purpose of this research was to evaluate the relationship between the structure of hyptolide and its epoxy hyptolide transformation and the antibacterial activity of Grampositive and Gram-negative bacteria strains.

\section{Hyptolide isolation and purification}

First, we isolated the hyptolide compound from Hyptis pectinata (L.) Poit methanolic extract using recrystallization methods. The hyptolide compound (yellowish) was obtained as much as $2.78 \mathrm{~g}(0.83 \%)$ from $335 \mathrm{~g}$ of leaves of dried Hyptis pectinata (L.) Poit. Hyptolide yields generally ranged from $0.30 \%$ to $0.94 \%$ (Achmad et al., 1987). The yield is much smaller than a previous research study which reported that the yield of isolation of the hyptolide compound from Hyptis pectinata (L.) Poit was $2.00 \%$ (Gorter, 1920). The percentage difference is due to the crop-taking season and geographical factors that have an important effect on the percentage of yield obtained (Agnolucci and De Lipsis, 2019). Thus, we determine the melting point to analyze the purity of hyptolide; the results showed that the hyptolide crystals have a melting point of $86.9^{\circ} \mathrm{C}-87.7^{\circ} \mathrm{C}$. A narrow melting point range $\left(0.5^{\circ} \mathrm{C}-2^{\circ} \mathrm{C}\right)$ usually indicates that the substance is fairly pure. These results are not much different from the results reported by previous research studies, like $88.5^{\circ} \mathrm{C}$ (Gorter, 1920), $88.5^{\circ} \mathrm{C}$
(Birch and Butler, 1964), $87^{\circ} \mathrm{C}-88^{\circ} \mathrm{C}$ (Achmad et al., 1987), and $87^{\circ} \mathrm{C}-88^{\circ} \mathrm{C}$ (Suzery, 1989). Furthermore, to confirm its purity, spot analysis was carried out by TLC with various mobile phases. The hyptolide compound gives a single brown spot with a retention factor $(R f)$ value between 0.45 and 0.65 (Table 1). Based on these results, it can be concluded that the hyptolide crystal isolated from Hyptis pectinata extract is a pure compound, causing the fairly pure crystalline compounds to usually have the smallest range $\left(0.5^{\circ} \mathrm{C}-2^{\circ} \mathrm{C}\right)$, a sharp melting point (Klepper, 2009), and a single spot on TLC analysis (Marston, 2011).

\section{Hyptolide transformation using $\mathrm{mCPBA}$ reaction and its characterization}

Hyptolide epoxidation reaction approaches are based on the method developed by Bradley et al. (1997) and Hussain et al. (2014), with slight modification (Fig. 1). The TLC analysis has a retention factor $(R f)$ value of 0.44 as a single soft brown zone (A) and 0.32 as a single black zone (B) on the TLC chromatogram showed the hyptolide and epoxy hyptolide separation, respectively (Fig. 2). The existence of a single-spot retention factor $(R f)$ showed that the compound of isolation was perfectly pure of hyptolide and its epoxide. Based on the different $\mathrm{R} f$ values between the two spots, it can be concluded that the spots are different compounds. After purification under the recrystallization method, we confirmed the purity of two compounds using a melting point assay. The purity assessment is the key parameter and the most critical in the case of a novel compound to which a biological is ascribed (Pauli et al., 2014). Our results showed that epoxy hyptolide has a melting point of $79^{\circ} \mathrm{C}-80^{\circ} \mathrm{C}$ which is different from the hyptolide melting point of $86.9^{\circ} \mathrm{C}-87.7^{\circ} \mathrm{C}$. These results indicated that the epoxy hyptolide was successfully formed and had different characteristics from the previous compound. On the other hand, a small range of melting points $\left(0.5^{\circ} \mathrm{C}-2^{\circ} \mathrm{C}\right)$ means that the material is relatively pure (Klepper, 2009).

NMR analysis of hyptolide and its epoxide chemical structure was further elucidated. The ${ }^{1} \mathrm{H}$ NMR analysis showed the same results as the previous studies (Sabitha et al., 2014). The ${ }^{1} \mathrm{H}$ NMR spectrum of epoxy hyptolide is shown in Table 2. The ${ }^{1} \mathrm{H}$ NMR spectrum and chemical shift of epoxide compounds indicated that the epoxy hyptolide compound had been formed. It is shown by the presence of the hydrogen spectrum corresponding to the composition of the epoxy hyptolide proton. The specific NMR spectrum shows that epoxy hyptolide is formed in the presence of three proton spectra with singlet multiplicity, and ${ }^{3} \mathrm{H}$ integration with a chemical shift of about $2.00 \mathrm{ppm}$ which shows that the methyl group is attached to carbon atoms C-19, C-23, and C-27. Meanwhile, the proton on the $\mathrm{C}-14$ atom is shown by the three integrated doublet peaks in the chemical shift of about $1.21 \mathrm{ppm}$. The specific spectrum of epoxy hyptolide is shown at $5.10 \mathrm{ppm}$ with the integration of two protons which is the proton spectrum at $\mathrm{C}-2$ and $\mathrm{C}-10$. The $\mathrm{C}-2$ and $\mathrm{C}-10$ spectra produced are the same due to the same chemical environment. Atoms C-2 and C-10 are both directly bonded to oxygen atoms which are electronegative so that the resulting spectrum peaks are in the deshielding region (5.10 ppm). The spectral peaks of C-8 and C-9 which are carbon atoms in cyclic epoxide are shown in relatively close chemical shifts, namely 3.20 and 3.26 ppm, with double doublet multiplicity (dd). The C-5 and C-6 spectra are in the deshielding area, namely 
Table 1. TLC analysis of hyptolide.

\begin{tabular}{lc}
\hline Mobile phase & Retention factor $\mathrm{R}_{f}$ \\
\hline Ether & 0.55 \\
Chloroform & 0.65 \\
Benzena & - \\
Methanol & 0.60 \\
Ether : chloroform $(3: 2)$ & 0.45 \\
\hline
\end{tabular}

The stain detection is carried out with 254 UV lamps and spraying with dilute sulfuric acid.<smiles>CC(=O)OC(/C=C\[C@H]1CC=CC(=O)O1)CC(OC(C)=O)[C@@H](C)OC(C)=O</smiles>

Hyptolide

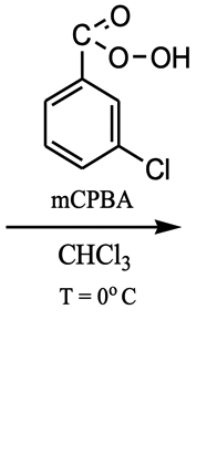

$\mathrm{CH}_{3}$<smiles>CC(=O)OC(CC(OC(C)=O)[C@@H](C)OC(C)=O)C1OC1[C@H]1CC=CC(=O)O1</smiles>

Epoxy hyptolide

Figure 1. Scheme showing the reaction between epoxy hyptolide and hyptolide epoxidation with a ratio of 1 mol of hyptolide and $2 \mathrm{~mol}$ of mCPBA using 0.736 grams of hyptolide crystal dissolved into $15 \mathrm{ml}$ of chloroform and $0.690 \mathrm{~g}$ of mCPBA as a reactant for 24 hours.

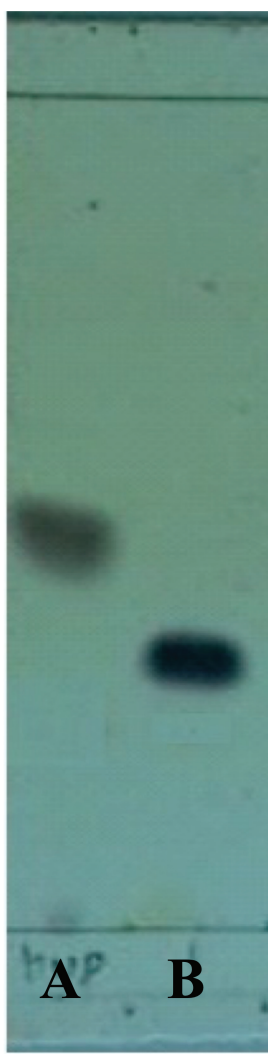

Figure 2. TLC separation of the hyptolide and epoxy hyptolide on silica gel 60 F254. Mobile phase using chloroform :ether (10:1). Sample application of 10 $\mu$ l: (A) hyptolide and (B) epoxy hyptolide reaction products. 
6.06 and $6.87 \mathrm{ppm}$, due to the position of the C-5 and C-6 atoms double bond (pi-bonding interaction), and are in the ring system resulting in chemical shear in the deshielding area. The peak of the spectrum at $5.00 \mathrm{ppm}$ chemical shift belongs to the proton on the $\mathrm{C}-12$ atom which is directly attached to the oxygen atom so that the spectrum is also in the deshielding region. The $\mathrm{C}-12$ spectrum has triplet multiplicity because it is adjacent to three protons, namely two protons in the $\mathrm{C}-11$ atom and one proton in $\mathrm{C}-13$. The $\mathrm{C}-13$ spectrum which is directly bound to oxygen atoms causing a peak to appear in the chemical shear deshielding is also at 4.61 ppm with multiplet multiplicity $(\mathrm{m})$ because it is adjacent to three protons at C-14 and one proton at C-12 (Fig. 3).

On the other hand, we also evaluated using fingerprint analytical technique of FTIR spectroscopy to confirm the function group of epoxy hyptolide. Figure 4 shows epoxy hyptolide FTIR spectra at midinfrared region corresponding to wavenumbers of $4,000-400 \mathrm{~cm}^{-1}$ along with prominent peaks due to infrared transmission. Table 3 shows the compilation of the functional groups responsible for infrared transmission which may be correlated with the chemical compound of epoxy hyptolide. The IR spectrum of epoxy hyptolide showed the absorption of epoxide wavenumbers at $750-840$ and $1,250 \mathrm{~cm}^{-1}$, which indicate the presence of stretching $\mathrm{C}-\mathrm{O}$ epoxide. The stretching is supported by the presence of $\mathrm{C}-\mathrm{H}$ epoxide absorption at $2,990-3,050 \mathrm{~cm}^{-1}$. In addition, the absorption of lactone at $1,735-1,750 \mathrm{~cm}^{-1}$ shows the stretching $\mathrm{C}=\mathrm{O}$ lactone or ester which is supported by the absorption of $\mathrm{C}-\mathrm{O}$ lactone and ester at $1,000-1,300 \mathrm{~cm}^{-1}$. Interestingly, no stretching vibration of $\mathrm{C}=\mathrm{C}$ in the epoxy hyptolide product indicates that the infrared spectrum of the product is different from pure hyptolide. After confirming the structure and functional groups, the antibacterial activity was analyzed using disk diffusion methods.

\section{Antibacterial activity of hyptolide on Gram-positive and Gram-negative bacteria}

This study shows antibacterial activity against clinically important Gram-positive and Gram-negative strains of a bacterial pathogen. The natural antibacterial agent found to be inhibitory to a broad range of bacteria has been reproducibly demonstrated at a high antagonistic capacity. In this investigation, we explored the effect of Hyptis pectinata extracts, hyptolide, and epoxy hyptolide on the antibacterial activity against Gram-positive and Gram-negative bacteria strains, Staphylococcus aureus, Streptococcus mutants, and Bacillus subtilis, as a Gram-positive bacterium. The presence of an IZ around the disks has determined the antibacterial activity. The concentration of the Hyptis pectinata extract, hyptolide, and epoxy hyptolide tested, ranging from 25 to $75 \mathrm{mg} / \mathrm{ml}$, showed significant antibacterial activity against bacterial strains compared with amoxicillin $(25 \mathrm{mg} / \mathrm{ml})$ as a positive control. The high dose of a hyptolide revealed the maximum activity $(28.00 \pm 0.42$ IZ) against Gram-positive Bacillus subtilis bacteria, followed by Streptococcus mutants (20.00 $\pm 0.28 \mathrm{IZ})$ and Staphylococcus aureus (15.50 \pm 0.92 IZ) (Fig. 5A and B). Interestingly, the presence of Hyptis pectinata extracts, hyptolide, and epoxy hyptolide on the medium for 24 hours highly increased an IZ and exhibited strong antibacterial activity in a dose-dependent manner. The Hyptis pectinata extracts, hyptolide, and epoxy hyptolide showed activity against all the three types of bacteria. The diameter of the IZ produced was sensitive in Bacillus subtilis due to the addition of those samples. But interestingly, the strongest activity to Bacillus subtilis was obtained by the hyptolide compared to Hyptis pectinata extract and epoxy hyptolide. The presence of hyptolide may be responsible for the antibacterial activity. A glance at the active products listed in Figure 5A and $\mathrm{B}$ indicated that the presence of a,b-unsaturated

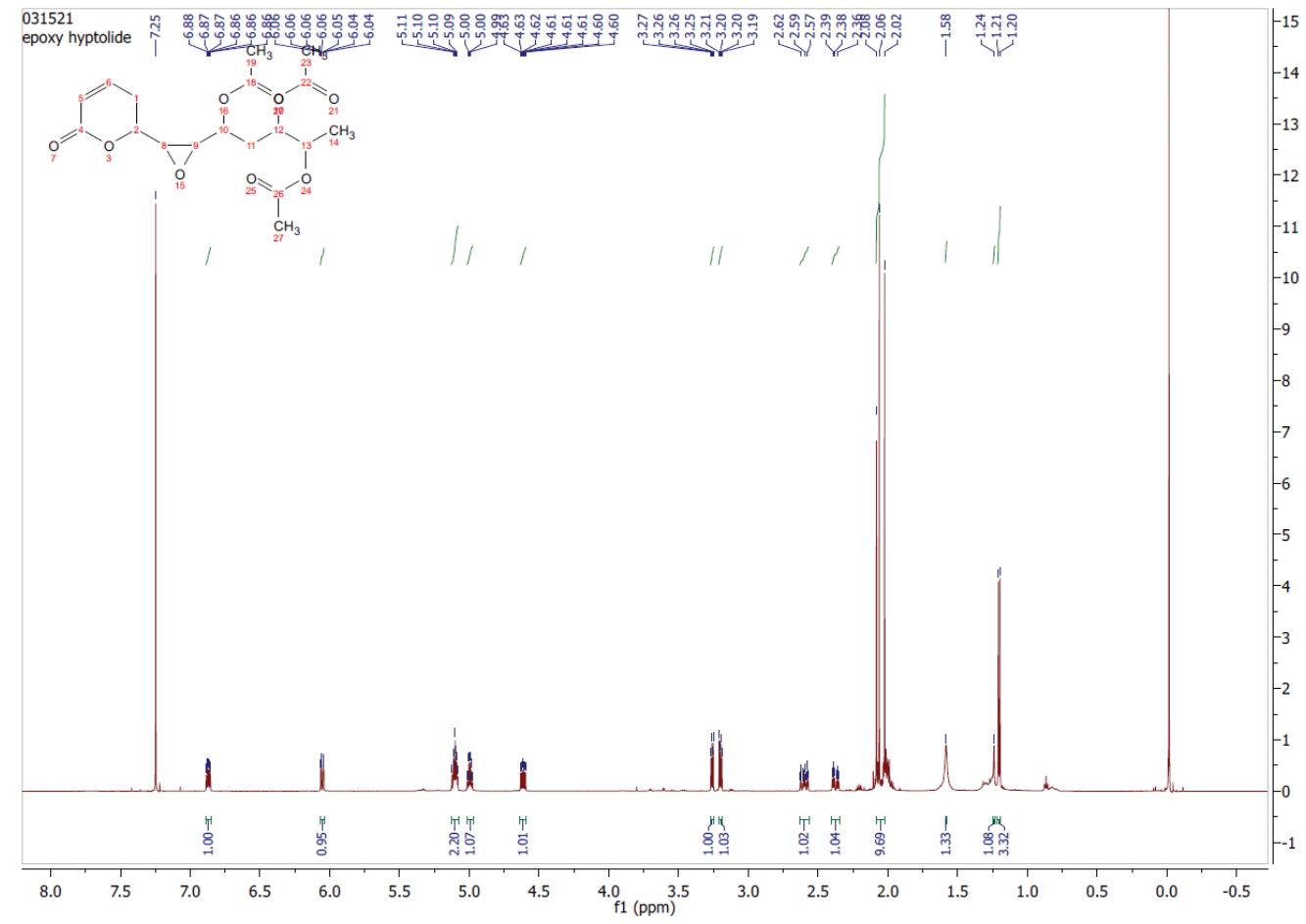

Figure 3. ${ }^{1} \mathrm{H}$ NMR spectrum of epoxy hyptolide (500 MHz, $\left.\mathrm{CDCl}_{3}\right)$. 


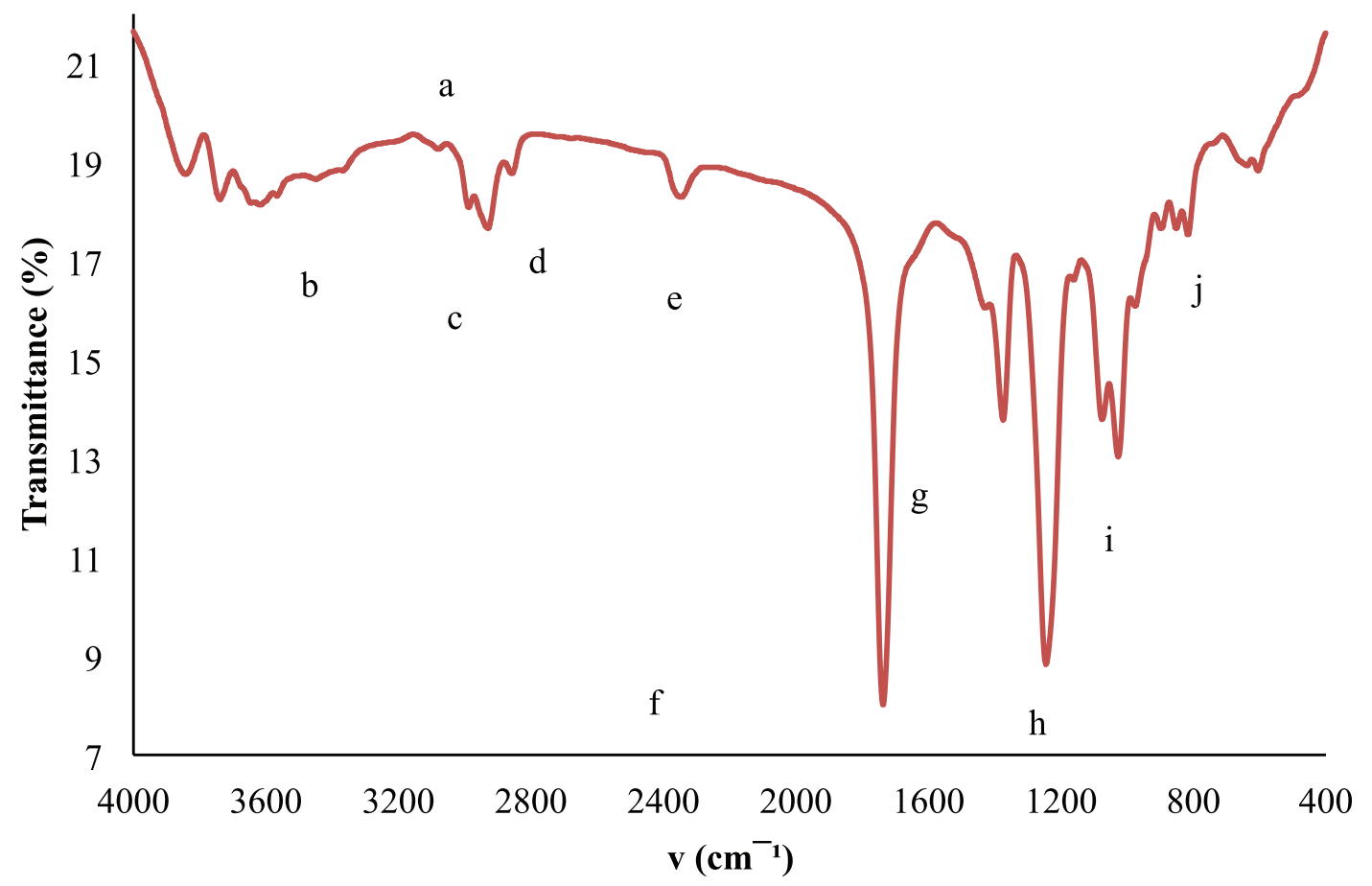

Figure 4. FTIR transmittance spectrum of epoxy hyptolide.

Table 2. ${ }^{1} \mathrm{H}$ NMR chemical shifts observed from the epoxidation of hyptolide.

\begin{tabular}{cc}
\hline \multirow{2}{*}{ Atomic $\mathbf{C}$ number } & $\boldsymbol{\delta} \mathbf{H}(\mathbf{p p m})$, multiplicity, integration \\
\cline { 2 - 2 } 1 & Epoxy hyptolide \\
\hline 2,10 & $2.38 ; 2.59(\mathrm{ddd}, 1.02 \mathrm{H} ; 1.04 \mathrm{H})$ \\
5 & $5.10(\mathrm{~m}, 2.20 \mathrm{H})$ \\
6 & $6.06(\mathrm{dt}, 0.95 \mathrm{H})$ \\
8 & $6.87(\mathrm{ddd}, 1.00 \mathrm{H})$ \\
9 & $3.20(\mathrm{dd}, 1.03 \mathrm{H})$ \\
11 & $3.26(\mathrm{dd}, 1.00 \mathrm{H})$ \\
12 & $1.58 ; 1.24(\mathrm{dd}, 1.33 \mathrm{H} ; 1.08 \mathrm{H})$ \\
13 & $5.00(\mathrm{dt}, 1.07 \mathrm{H})$ \\
14 & $4.61(\mathrm{~m}, 1.01 \mathrm{H})$ \\
19 & $1.21(\mathrm{~d}, 3 \mathrm{H})$ \\
23 & $2.02(\mathrm{~s}, 3 \mathrm{H})$ \\
27 & $2.06(\mathrm{~s}, 3 \mathrm{H})$ \\
\hline
\end{tabular}

Table 3. The functional groups are responsible for the absorption of epoxy hyptolide in the IR.

\begin{tabular}{cccl}
\hline Assignment & Wavenumbers & Functional groups & \\
\hline & Epoxy hyptolide & Hyptolide & \\
a & $3,078 \mathrm{~cm}^{-1}$ & $3,080 \mathrm{~cm}^{-1}$ & Stretching vibration of C-H sp2 \\
$\mathrm{b}$ & $2,992 \mathrm{~cm}^{-1}$ & - & Stretching vibration of C-H epoxide \\
$\mathrm{c}$ & $2,938 \mathrm{~cm}^{-1}$ & $2,960 \mathrm{~cm}^{-1}$ & Stretching vibration of C-H sp3 from metal \\
$\mathrm{d}$ & $2,854 \mathrm{~cm}^{-1}$ & $2,853 \mathrm{~cm}^{-1}$ & Stretching vibration of C-H sp3 from -CH2- \\
$\mathrm{e}$ & $1,740 \mathrm{~cm}^{-1}$ & $1,740 \mathrm{~cm}^{-1}$ & Stretching vibration of conjugated carbonyl $(\mathrm{C}=\mathrm{O})$ group \\
$\mathrm{f}$ & - & $1,640 \mathrm{~cm}^{-1}$ & Stretching vibration of C=C not conjugated \\
$\mathrm{g}, \mathrm{i}$ & 1,377 and $1,033 \mathrm{~cm}^{-1}$ & 1,225 and $1,170 \mathrm{~cm}^{-1}$ & Stretching vibration of C-O lactone and ester \\
$\mathrm{h}, \mathrm{j}$ & 1,250 and $814 \mathrm{~cm}^{-1}$ & - & Stretching vibration of C-O epoxide \\
\hline
\end{tabular}




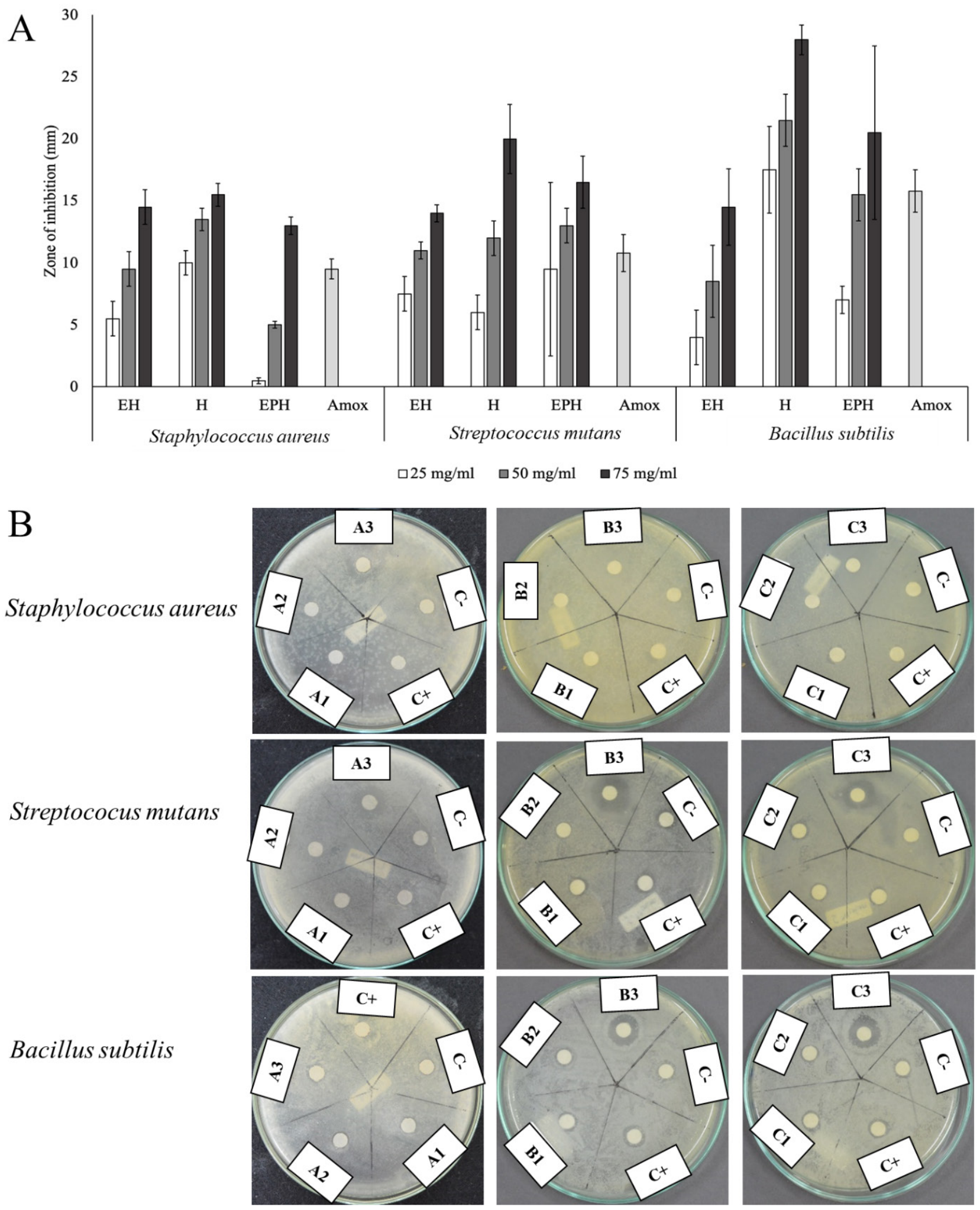

Figure 5. (A) Antibacterial activity of Hyptis pectinata methanolic extract, hyptolide, epoxide hyptolide, and amoxicillin against gram-positive organisms (mean \pm SEM) $(\mathrm{mm})$. Values are means of triplicate determination $(n=3) \pm$ standard deviations. $* \mathrm{EH}=$ methanolic extract of Hyptis pectinata; $\mathrm{H}=$ hyptolide; $\mathrm{EPH}=$ epoxy hyptolide; Amox = Amoxicillin. (B) Morphological growth inhibition of extract, hyptolide, and epoxy hyptolide against gram-positive bacteria. A1: extract 25 mg/ $\mathrm{ml}$; A2: extract $50 \mathrm{mg} / \mathrm{ml}$; A3: extract $75 \mathrm{mg} / \mathrm{ml}$; B1: hyptolide $25 \mathrm{mg} / \mathrm{ml}$; B2: hyptolide $50 \mathrm{mg} / \mathrm{ml}$; B3: hyptolide $75 \mathrm{mg} / \mathrm{ml}$; C1: epoxy hyptolide $25 \mathrm{mg} / \mathrm{ml}$; C2: epoxy hyptolide 50mg/ml; C3: epoxy hyptolide $75 \mathrm{mg} / \mathrm{ml}$; C+: amoxicillin; C-: control negative. 

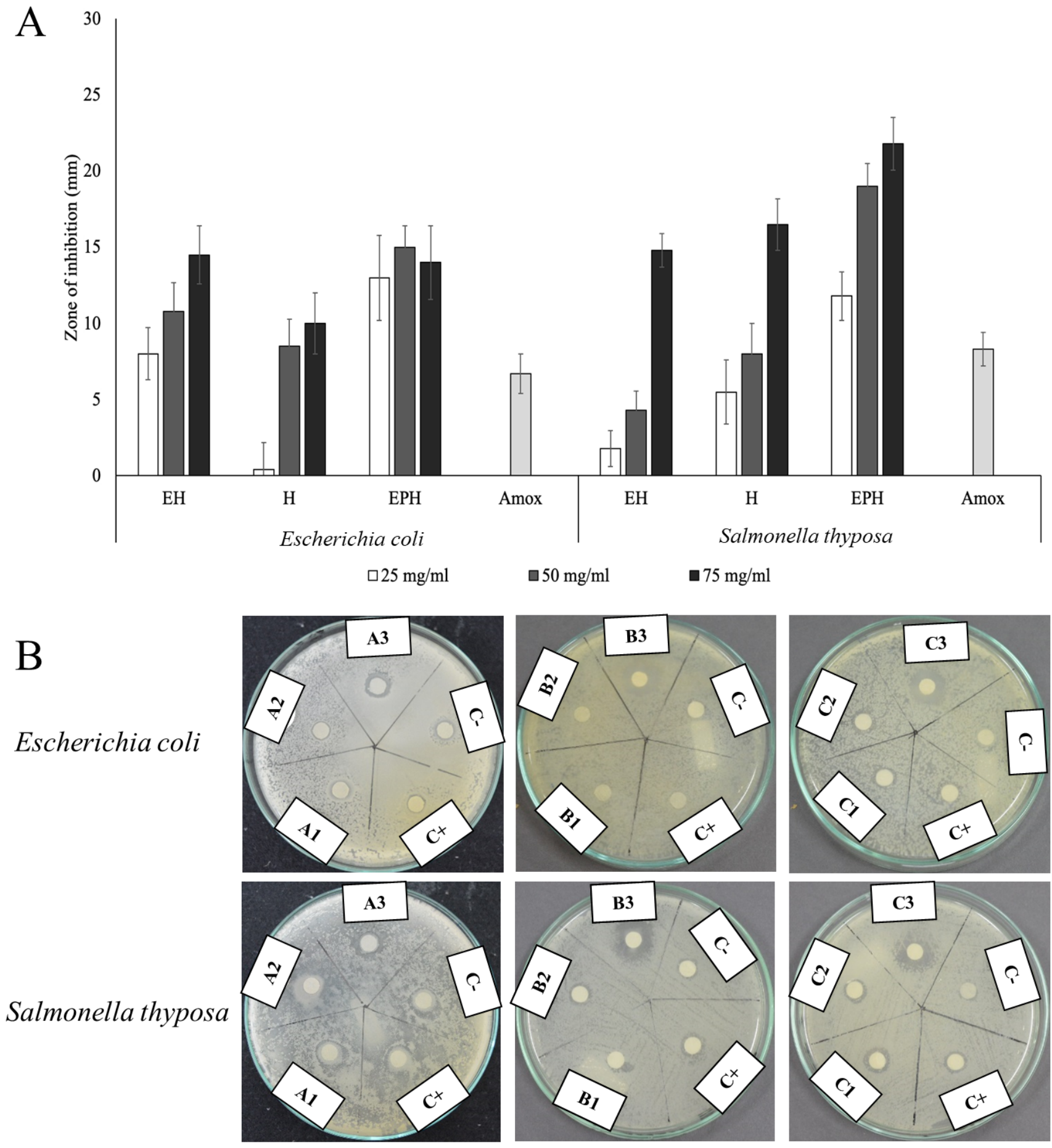

Figure 6. (A) Antibacterial activity of Hyptis pectinata methanolic extract, hyptolide, epoxide hyptolide, and amoxicillin against gram-negative organisms (mean \pm SEM.) $(\mathrm{mm})$. Value are means of triplicate determination $(n=3) \pm$ standard deviations. $* \mathrm{EH}=$ methanolic extract of Hyptis pectinata; $\mathrm{H}=$ hyptolide; EPH $=$ epoxy hyptolide; Amox = amoxicillin. (B) Morphological growth inhibition of extract, hyptolide, and epoxy hyptolide against gram-negative bacteria. A1: extract $25 \mathrm{mg} /$ $\mathrm{ml}$; A2: extract $50 \mathrm{mg} / \mathrm{ml}$; A3: extract 75mg/ml; B1: hyptolide $25 \mathrm{mg} / \mathrm{ml}$; B2: hyptolide $50 \mathrm{mg} / \mathrm{ml}$; B3: hyptolide $75 \mathrm{mg} / \mathrm{ml}$; C1: epoxy hyptolide $25 \mathrm{mg} / \mathrm{ml}$; C2: epoxy hyptolide $50 \mathrm{mg} / \mathrm{ml}$; C3: epoxy hyptolide $75 \mathrm{mg} / \mathrm{ml}$; C+: amoxicillin; C-: control negative.

lactones in the molecule is necessary despite not being the only structural requirement for antibacterial activity (Cartagena and Bardon, 2008). In fact, the Hyptis pectinata extract is not more active than hyptolide. The non-effective antibacterial activity of the plant extract in this study can be attributed to the presence of various bioactive components that work antagonistically (Debalke et al., 2018). On the other hand, the Hyptis pectinata extract activity against Gram-positive bacteria indifferent with the findings of Miranda et al. (1993) and Santos et al. (2008) that obtain the minimum inhibitory concentration (MIC) of $12.5 \mu \mathrm{g} / \mathrm{ml}$ under 
pectinolades $\mathrm{A}$ and $\mathrm{C}$ treatment (another secondary metabolite of Hyptis pectinata extract)

In the second set of experiments, the Hyptis pectinata extract, hyptolide, and epoxy hyptolide were tested against Gramnegative bacteria. Escherichia coli and Salmonella thyposa were used in the test. The maximum antibacterial activity on Gramnegative Salmonella thyposa $(21.80 \pm 0.74 \mathrm{IZ})$ is more potent than that of Escherichia coli $(14.00 \pm 0.42 \mathrm{IZ})$ due to the presence of a high concentration of epoxy hyptolide (Fig. 6A and B). The antibacterial activity on Gram-negative bacteria shows that the best inhibitory zone diameter results were obtained from the epoxy hyptolide compound in Escherichia coli and Salmonella thyposa bacteria compared with the results of the inhibitory zone of hyptolide and Hyptis pectinata extract. This means that the epoxy compounds are better used for Gram-negative bacteria than pure hyptolide and Hyptis pectinata extracts that contain various bioactive compounds. Interestingly, these results are different from those conducted by Miranda et al. (1993), on Escherichia coli Gram-negative bacteria using pure hyptolide compounds that do not produce inhibitory zones. The other reason may also be that the antibacterial activity increased due to the presence of epoxy structure; for Gramnegative bacteria, the epoxy structure individually showed more antibacterial activities than that of Gram-positive bacteria. This may be due to the presence of an extra outer membrane in Gramnegative bacteria, which consists of lipopolysaccharide and makes them permeable to lipophilic compounds, such as epoxy structure, whereas for Gram-positive bacteria, they have a peptidoglycan outer layer that is a hydrophilic barrier. It underlies the activity of hyptolide isolates more effectively because hyptolide is a polar compound. Even if the antibacterial activity of the plant extract was very low in this study, different researches revealed that the plant extract is more effective than the isolated compound of the extract.

In contrast to amoxicillin which showed lower activity in both Gram-positive and Gram-negative bacteria compared to the sample, amoxicillin has an IZ diameter of 7.58 and 6.69 against Bacillus subtilis and Escherichia coli, respectively. The difference in sensitivity between Gram-negative and Gram-positive bacteria may be due to the variability in the composition of their cell wall. The bacterial cell wall of Gram-positive bacteria consists of 100 layers of peptidoglycans. This is obviously an oversimplification as an explanation and other mechanisms are likely to play a part. Gram-negative bacteria resistance to b-lactam antibiotics, such as amoxicillin, originates from the lactamase enzyme being secreted in the periplasmic space between the thin outer membrane and the cytoplasmic membrane (Henley-Smith et al., 2014).

These results conclude that the difference in bacterial sensitivity to antibacterial is influenced by the structure of the bacterial cell wall. Gram-positive bacteria tend to be more sensitive to antibacterial because the structure of Gram-positive bacterial cell walls is simple, making it easier for antibacterial compounds to enter into Gram-positive bacterial cells. The underlying mechanisms of hyptolide on the inhibited bacterial growth need to be explored further.

\section{CONCLUSION}

Newly developed epoxy hyptolide compounds were prepared in good yield and characterized by various instrumental techniques. It has been observed that the presence of epoxy ring enhances antibacterial activity, especially on Gram-negative bacteria. More importantly, our findings suggest that epoxy hyptolide has the potential to be developed as a natural antibacterial agent with better effects and possibly fewer resistance side effects

\section{ACKNOWLEDGMENT}

The authors acknowledge the fundamental research grant from the Ministry of Research, Technology, and Higher Education for funding and One Professor One Candidate (OPOC) program Universitas Diponegoro.

\section{CONFLICT OF INTEREST}

The authors declare that there are no conflicts of interest relevant to the contents of this article.

\section{FUNDING}

None.

\section{AUTHORS' CONTRIBUTIONS}

The contributions of each author are stated as follows: $\mathrm{BC}$ and $\mathrm{MZ}$ contributed to the conception of the work; $\mathrm{BC}, \mathrm{MZ}$, NDA, and WW contributed to the acquisition of the work; NDA, $\mathrm{BC}$ and DNB contributed to the analysis and interpretation of data; NDA, BC, and MZ contributed to drafting the work; BC and $\mathrm{MZ}$ contributed to revising the work critically; $\mathrm{BC}$ was responsible for giving the final approval of the manuscript.

\section{REFERENCES}

Achmad S, Hoyer T, Kjaer A, Makmur L, Norrestam R. Molecular and crystal structure of hyptolide, a naturally occuring $\alpha, \beta$ unsaturated $\delta$-lactone. Acta Chem Scand, 1987; B41:599-609.

Agnolucci P, De Lipsis V. Long-run trend in agricultural yield and climatic factors in Europe. Clim Change, 2019; 159:1-21.

Ahmad FB, Mohd Sallehuddin NKN, Assim Z. Chemical constituents and antiviral study of Goniothalamus velutinus. Malays J Fundam Appl Sci, 2014; 6(1):72-5.

Almtorp GT, Hazell AC, Torssell KBG. A lignan and pyrone and other constituents from Hyptis capitata. Phytochemistry, 1991; 30(8):2753-6.

Amalina ND, Suzery M, Cahyono B. Cytotoxic activity of Hyptis pectinata extracts on MCF-7 human breast cancer cells. Indones J Cancer Chemoprevention, 2020; 10:1-6.

Andrade TA, Freitas TS, Araújo FO, Menezes PP, Dória GAA, Rabelo AS, Quintans-Júnior LJ, Santos MRV, Bezerra DP, Serafini MR, Menezes IRA, Nunes PS, Araújo AAS, Costa MS, Campina FF, Santos ATL, Silva ARP, Coutinho HDM. Physico-chemical characterization and antibacterial activity of inclusion complexes of Hyptis martiusii Benth essential oil in $\beta$-cyclodextrin. Biomed Pharmacother, 2017; 89:201-7.

Asy M, Suzery M. In silico study: the anticancer potency of hyptolide and analogue compounds through mechanism of $\alpha$-tubulin. Int $\mathrm{J}$ Pharm Bio, 2019; 2019:243-8.

Basílio IJLD, Agra MDF, Rocha EA, Leal CKA, Abrantes HF. Comparative pharmacobotanical study of the leaves of Hyptis pectinata (L.) poit. and Hyptis suaveolens (L.) poit. (Lamiaceae). Acta Farm Bonaer, 2006; 25(4):518-25.

Birch AJ, Butler DN. 799 The structure of hyptolide. J Chem Soc, $1964 ; 1: 4167-8$

Boalino DM, Connolly JD, McLean S, Reynolds WF, Tinto WF. $\alpha$-Pyrones and a $2(5 \mathrm{H})$-furanone from Hyptis pectinata. Phytochemistry, 2003; 64(7):1303-7.

Bradley LM, Springer JW, Delate GM, Goodman A. Epoxidation of geraniol: an advanced organic experiment that illustrates asymmetric synthesis. J Chem Educ, 1997; 74(11):1336-8.

Cartagena E, Montanaro S, Bardon A. Improvement of the antibacterial activity of sesquiterpene lactones. Rev Latinoam Quim, 2008, 36(2):43-50. 
Debalke D, Birhan M, Kinubeh A, Yayeh M. Assessments of antibacterial effects of aqueous-ethanolic extracts of sida rhombifolia's aerial part. Sci World J, 2018; 2018:1-8.

Falcao RA, Nascimento PLA, Souza SA De, Silva TMG, Queiroz AC De, Matta CBB, Moreira MSA, Camara CA, Silva TMS. Antileishmanial phenylpropanoids from the leaves of Hyptis pectinata (L.) poit. Evid Based Complement Alternat Med, 2013;2013:1-7.

Founou RC, Founou LL, Essack SY. Clinical and economic impact of antibiotic resistance in developing countries: a systematic review and meta-analysis. PLoS One, 2017; 12(12):1-18.

Franzotti EM, Bomfim KBR, Moreno MPN, Marchioro M, Antoniolli AR. Antinociceptive and antiedematogenic effects of the aqueous extract of Hyptis pectinata leaves in experimental animals. $\mathrm{J}$ Ethnopharmacol, 2001; 76:81-6.

Gorter K. Hyptolide, a bitter principle of Hyptis pectinata, poit. Bulletin du Jardin Botanique de Buitenzorg, 1920; V2:327-37.

Henley-Smith CJ, Steffens FE, Botha FS, Lall N. Predicting the influence of multiple components on microbial inhibition using a logistic response model - a novel approach. BMC Complement Altern Med, 2014; $14: 1-10$.

Husain A, Shaharyar M. Synthesis and antibacterial activity of epoxides derived from chalcones. 2015; 17(1):624-6.

Hussain H, Al-Harrasi A, Green IR, Ahmed I, Abbas G, Rehman NU. Meta-chloroperbenzoic acid (mCPBA): a versatile reagent in organic synthesis. RSC Adv, 2014; 4(25):12882-917.

Inceoglu B, Jinks SL, Ulu A, Hegedus CM, Georgi K, Schmelzer KR, Wagner K, Jones PD, Morisseau C, Hammock BD. Soluble epoxide hydrolase and epoxyeicosatrienoic acids modulate two distinct analgesic pathways. Proc Natl Acad Sci U S A, 2008; 105(48):18901-6.

Janice GS. Key concepts - mass spectrometry, infrared spectroscopy and nuclear magnetic resonance spectroscopy. Organic Chemistry. 2nd edition, McGraw-Hill, New York, NY, pp 485-525, 2008.

Klepper RR. Melting point determination: purity and identity of crystalline. 2009.

Kumar S. Tumorigenicity of racemic and optically pure bay region diol epoxides and other derivatives of the nitrogen heterocycle dibenz[a,h]acridine on mouse skin. Carcinog, 2001; 22(6):951-5.

Luzuriaga-Quichimbo CX, Blanco-Salas J, Cerón-Martínez CE, Stanković MS, Ruiz-Téllez T. On the possible chemical justification of the ethnobotanical use of hyptis obtusiflora in amazonian Ecuador. Plants, 2018; 7(4):104

Mama M, Teshome T, Detamo J. Antibacterial activity of honey against methicillin-resistant Staphylococcus aureus: a laboratory-based experimental study. Int J Microbiol, 2019; 2019:1-8.

Marco-Contelles J, Molina MT, Anjum S. Naturally occurring cyclohexane epoxides: sources, biological activities and synthesis. Chem Rev, 2004; 104(6):2857-99.

Marston A. Thin-layer chromatography with biological detection in phytochemistry. J Chromatogr A, 2011; 1218(19):2676-83.Matsunaga N, Hayakawa K. Estimating the impact of antimicrobial resistance. Lancet Glob Health, 2018; 6(9):934-35.

Melo GB, Silva RL, Melo VA, Antoniolli ÂR, Michellone PRT, Zucoloto S, De Souza MEJ, Gomes MCJ, Correia RB, De Castro-e-Silva O. Proliferative effect of the aqueous extract of Hyptis pectinata on liver regeneration after partial hepatectomy in rats. Acta Cir Bras, 2006; 21:33-6.

Miranda RP, Hernadez L, Villavicencio MJ, Novelo M, Ibarra P. Structure and stereochemistry of pectinolides AC, novel antimicrobial and cytotoxic 5,6-dihydro-a- pyrones from Hyptis pectinata. J Nat Prod, 1993; 56(4):583-93.

Morisseau C, Schebb NH, Dong H, Ulu A, Aronov PA, Hammock BD. Role of soluble epoxide hydrolase phosphatase activity in the metabolism of lysophosphatidic acids. Biochem Biophys Res Commun, 2012; 419(4):796-800.

Nie Y, Sun Y, You QD. Synthesis and antibacterial activity of novel 10,11-epoxy acylide erythromycin derivatives. Chin Chem Lett, 2013; 24(3):183-85.
Pal SK, Childs BH, Pegram M. Triple negative breast cancer: unmet medical needs. Breast Cancer Res Treat, 2013; 125(3):627-36.

Pauli GF, Chen SN, Simmler C, Lankin DC, Gödecke, Jaki BU, Friesen JB, McAlpine JB, Napolitano JG. Erratum: importance of purity evaluation and the potential of quantitative $1 \mathrm{H}$ NMR as a purity assay, $\mathrm{J}$ Med Chem, 2014; 57:9220-31.

Peterson E, Kaur P. Antibiotic resistance mechanisms in bacteria: relationships between resistance determinants of antibiotic producers, environmental bacteria, and clinical pathogens. Front Microbiol, 2018; 9:1-21.

Razmavar S, Abdulla MA, Ismail SB, Hassandarvish P. Antibacterial activity of leaf extracts of baeckea frutescens against methicillin-resistant Staphylococcus aureus. Biomed Res Int, 2014; 2014:1-5.

Sabitha G, Raju A, Reddy CN, Yadav JS. Stereoselective total synthesis of (+)-hyptolide. RSC Adv, 2014; 4(3):1496-502.

Sachdeva S, Bhatia S, Mittal A, Sinha M. Synthesis, evaluation and in silico studies of 1,8-naphthyridine derivatives against antimicrobial activity. J Appl Pharm Sci, 2015; 5(7):53-9.

Santana FR, Luna-dulcey L, Antunes VU, Claudio F, Cominetti MR, Duarte MC, Silva JA. Evaluation of the cytotoxicity on breast cancer cell of extracts and compounds isolated from Hyptis pectinata (L.) poit. Nat Prod Res, 2019; 34(1):1-8.

Santos PO, Costa MDJC, Alves JAB, Nascimento PFC, De Melo DLM, Barbosa AM, Trindade RDC, Blank AF, Arrigoni-Blank MF, Alves PB, Do Nascimento MDPF. Chemical composition and antimicrobial activity of the essential oil of Hyptis pectinata (L.) poit. Quim Nova, 2008; 31(7):1648-52.

Singh Arora D, Jeet Kaur G, Kaur H. Antibacterial activity of tea and coffee: their extracts and preparations. Int J Food Prop, 2009; 12(2):286-94.

Suzery. Transformasi hiptolide. Institute Teknologi Bandung, Bandung, Indonesia, 1989

Suzery M, Cahyono B, Amalina ND. Antiproliferative and apoptosis effect of hyptolide from Hyptis pectinata (L.) poit on human breast cancer cells. J Appl Pharm Sci, 2020; 10(02):1-6.

Suzery M, Khumairoh S, Cahyono B. Total hyptolide of Indonesian Hyptis pectinata extracts in a various solvent using HPLC and UV-Vis spectroscopy and their toxicities. J Kim Sains Dan Apl, 2019; 22(6):305

Suzery M, Kusniawati E, Hudiyanti D, Cahyono B. Sintesis senyawa c18h2609 dati hiptolida hasil isolasi daun Hyptis pectinata. Reaktor, 2012; 14(1):68-72.

Thirunarayanan G, Vanangamudi G. Synthesis, spectral studies, antimicrobial and insect antifeedant potent keto oxiranes. Arab J Chem, 2016; 9:S269-77.

Ye XQ, Zhang LX, Zhang AJ, Chen XX, Zhang ZY. Studies on the syntheses and biological activities of 3-AryI-6-(1,1'-biphenyl-4-yl)7H-1,2,4-triazolo[3,4-b] [1,3,4]thiadiazines. Chem Res Chin Univ, 2002; 18(4):393-6.

Zhang Z, Chen M, Yu Y, Pan S, Liu Y. Antimicrobial susceptibility among gram-positive and gram-negative blood-borne pathogens collected between 2012-2016 as part of the tigecycline evaluation and surveillance trial. Antimicrob Resist Infect Control, 2018; 7(1):1-13.

\section{How to cite this article:}

Cahyono B, Suzery M, Amalina ND, Wahyudi, Bima DN. Synthesis and antibacterial activity of epoxide from hyptolide (Hyptis pectinata (L.) Poit) against Gram-positive and Gramnegative bacteria. J Appl Pharm Sci, 2020; 10(12):013-022. 